\title{
Sentinel Lymph Node Biopsy for Conjunctival and Ocular Adnexal Tumors
}

\author{
Sonal S. Chaugule and Bita Esmaeli
}

Sentinel lymph node biopsy (SLNB) is a method of detecting subclinical (microscopic) metastasis in regional lymph node at risk of metastasis and can be used to detect early metastasis from eyelid and conjunctival malignancies. Sentinel lymph node biopsy has been demonstrated to be technically feasible and have a reasonable positive yield for various eyelid and conjunctival cancers including melanoma, squamous cell carcinoma (SCC), sebaceous gland carcinoma (SGCa), and Merkel cell carcinoma (MCC); these cancers have various risks of regional lymph node metastasis (Table 5.1) [1-10].

The lymphatic drainage in the head and neck is complex and could be variable. However, commonly the lateral two-thirds of the upper eyelid, the lateral third of the lower eyelid, and the lateral half of the conjunctiva drain into the parotid (preauricular) lymph

\footnotetext{
S. S. Chaugule $(\bowtie)$

Ophthalmic Plastic Surgery, Orbit and Ocular Oncology, PBMA's H V Desai Eye Hospital, Pune, India e-mail: schaugule@eyecancercure.com

B. Esmaeli

Orbital Oncology and Ophthalmic Plastic Surgery

Service, Department of Plastic Surgery, The

University of Texas M. D. Anderson Cancer Center,

Houston, TX, USA

e-mail: besmaeli@mdanderson.org
}

Table 5.1 Rate of regional lymph node metastasis for eyelid tumors

\begin{tabular}{l|l|l}
\hline $\begin{array}{l}\text { Sr } \\
\text { No }\end{array}$ & Type of tumor & $\begin{array}{l}\text { Approximate rate of regional } \\
\text { lymph node metastasis (\%) }\end{array}$ \\
\hline 1 & $\begin{array}{l}\text { Eyelid and } \\
\text { conjunctival } \\
\text { melanoma }\end{array}$ & $20-24$ \\
\hline 2 & $\begin{array}{l}\text { Squamous cell } \\
\text { carcinoma }\end{array}$ & $7-24$ \\
\hline 3 & $\begin{array}{l}\text { Sebaceous gland } \\
\text { carcinoma }\end{array}$ & $7-20$ \\
\hline 4 & $\begin{array}{l}\text { Merkel cell } \\
\text { carcinoma }\end{array}$ & 21 \\
\hline
\end{tabular}

Data from references [1-10]

nodes, and the medial third of the upper eyelid, the medial two-thirds of the lower eyelid, and the medial half of the conjunctiva drain into the submandibular and deeper cervical nodes [11]. However, recent studies suggest that there is higher than expected preponderance of draining SLNs in the parotid and preauricular region even from the more medially located tumors [12].

SLNB is based on the concept of an orderly drainage of tumor cells through the lymphatic drainage system before dissemination in the bloodstream and involvement of other organs. The sentinel lymph nodes (SLNs) or first draining node(s) for a tumor can be identified by injecting tracer molecules into 
the tissue surrounding the tumor. Identification of SLN status provides the surgeon and the patient with valuable prognostic information [10]. Early detection and early management of micro-metastasis is believed to provide longterm survival benefits in oncological practices, and particularly in the recent era of availability of immune checkpoint inhibitors for metastatic melanoma and metastatic carcinomas and improved survival with these drugs, there is a more compelling reason to identify early metastatic disease in patients with biologically aggressive eyelid and conjunctival melanomas and carcinomas [13-16].

\section{Patient Selection Criteria}

Published studies and major reviews on SLNB in ocular and adnexal tumors have identified and described several risk factors for possible SLN involvement (Table 5.2) [2, 6, 7, 17-21].

Table 5.2 Risk factors for SLN involvement

\begin{tabular}{l|l|l}
\hline $\begin{array}{l}\text { Sr } \\
\text { No }\end{array}$ & Type of tumor & $\begin{array}{l}\text { Risk factor predicting SLN } \\
\text { involvement }\end{array}$ \\
\hline 1 & $\begin{array}{l}\text { Conjunctival } \\
\text { melanoma }\end{array}$ & $\begin{array}{l}\text { Tumor thickness } \geq 2 \mathrm{~mm} \\
\text { Non-limbal location of } \\
\text { conjunctival melanoma }\end{array}$ \\
\hline 1 & $\begin{array}{l}\text { Eyelid } \\
\text { melanoma }\end{array}$ & $\begin{array}{l}\text { Tumor thickness } \geq 1 \mathrm{~mm} \text { and } \\
\text { increasing Breslow depth } \\
\text { Presence of }>1 \text { mitotic figure/ } \\
\text { HPF } \\
\text { Presence of histopathologic } \\
\text { ulceration }\end{array}$ \\
\hline 2 & $\begin{array}{l}\text { Sebaceous } \\
\text { gland } \\
\text { carcinoma }\end{array}$ & $\begin{array}{l}\text { AJCC (7th edition) stage T2b } \\
\text { or }>\text { size } 10 \text { mm in the greatest } \\
\text { diameter }\end{array}$ \\
\hline 3 & $\begin{array}{l}\text { Squamous cell } \\
\text { carcinoma }\end{array}$ & $\begin{array}{l}\text { Tumors } \geq 2 \text { cm }(20 \text { mm) wide } \\
\text { Locally recurrent }\end{array}$ \\
\hline 4 & $\begin{array}{l}\text { Merkel cell } \\
\text { carcinoma }\end{array}$ & $\begin{array}{l}\text { Increasing diameter of the } \\
\text { lesion } \\
\text { Increasing thickness of the } \\
\text { lesion } \\
\text { Infiltrative growth pattern } \\
\text { High mitotic rate }\end{array}$ \\
\hline
\end{tabular}

HPF High-power field

Data from references [2, 6, 7, 17-21]

\section{Technique for Sentinel Lymph Node Biopsy [10]}

\section{Preoperative lymphoscintigraphy [22]}

(a) Topical anesthetic is applied on the eyelid surface.

(b) $0.3-0.4 \mathrm{mCi}$ of filtered technetium [Tc$99 \mathrm{~m}$ ] sulfur colloid $(0.2 \mathrm{ml}$ volume $)$ is injected in three to four spots around the eyelid lesion intradermally or subconjunctivally for conjunctival melanomas by an ophthalmic surgeon (precise injection of radioisotope into the area immediately surrounding the tumor is important to ensure the correct mapping of lymphatic channels).

(c) Serial scanning is carried out every $15 \mathrm{~min}$, once the first SLN is detected for visualization of all SLN.

(d) Single-photon emission CT (SPECT-CT) is utilized to improve anatomic resolution and precise localization of SLN (Fig. 5.1a, b).

2. Surgical procedure

(a) Ophthalmic surgeon: On the day of the planned primary surgical tumor resection, technetium-labeled sulfur colloid [Tc-99 m] is injected as described above in preoperative holding area approximately $90 \mathrm{~min}$ before the primary tumor resection; in some instances, if the preoperative SPECT/CT or lymphoscintigraphy took place the day before the planned surgery, there may not be a need for reinjection of technetium.

(b) Head and neck or another oncologic surgeon: Intraoperatively, a handheld gamma probe is used to localize the SLNs (Figs. 5.2 and 5.3). They are defined as lymph nodes that have radioactivity counts at least twice as high as the level of background radioactivity.

(c) The SLNs are then dissected and excised (Fig. 5.4).

(d) The lymph node basin around the "hot" nodes is scanned again to look for any other SLNs that have high radioactive uptake. This is continued until little or no radioactivity is detectable in the draining lymph node basins. 

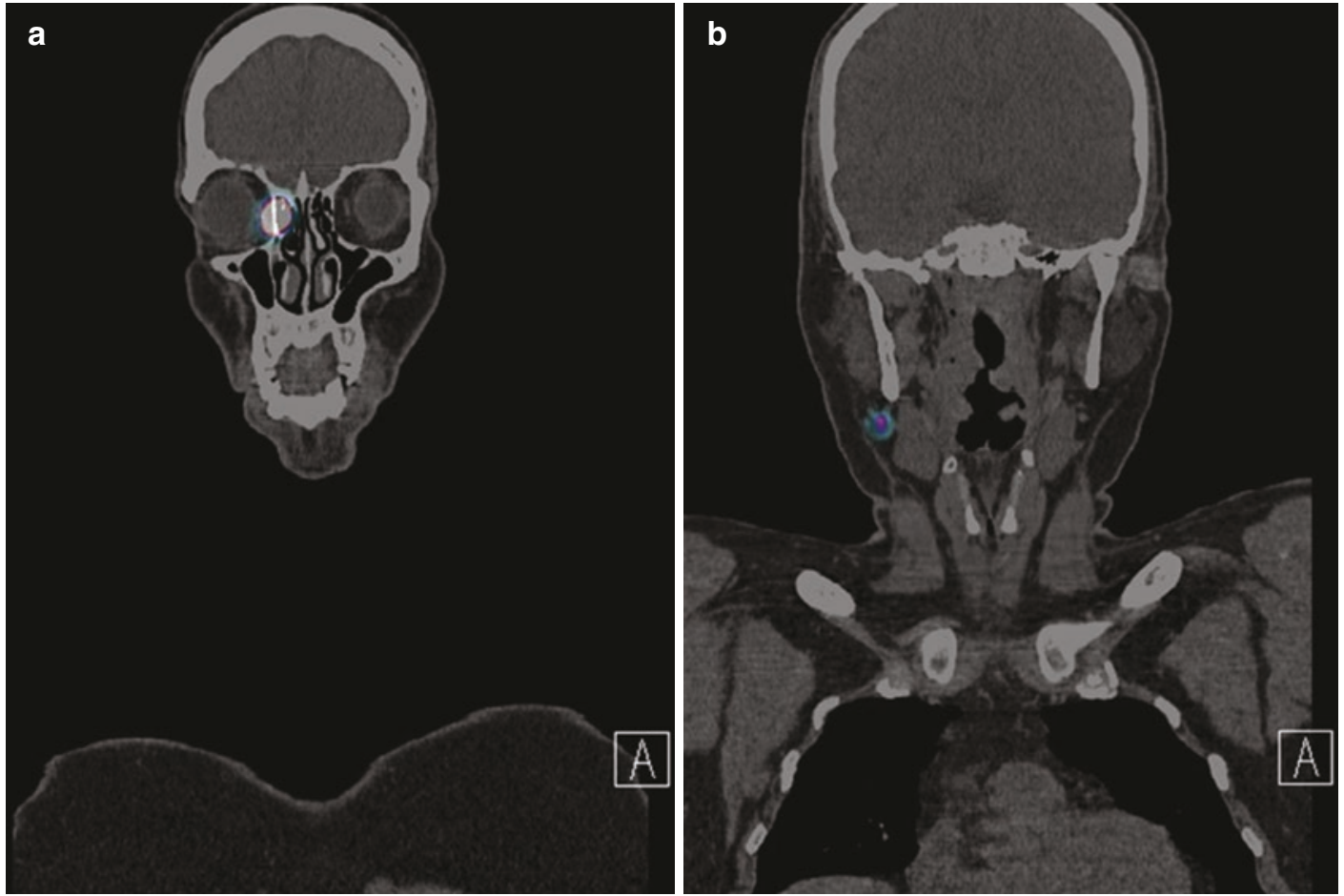

Fig. 5.1 Single-photon emission CT (SPECT-CT) image of primary eyelid sebaceous gland carcinoma (a) and of the sentinel lymph node (b)

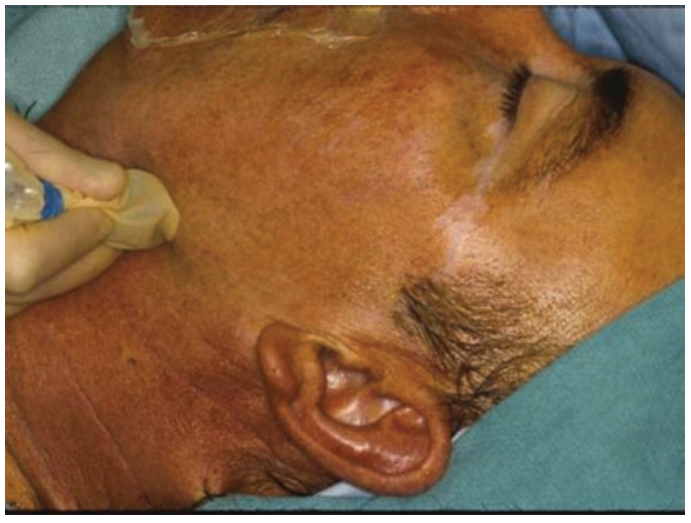

Fig. 5.2 Intraoperative use of handheld gamma probe to localize the sentinel lymph node

\section{Histopathologic Evaluation of SLN}

1. SLNs are serially sectioned using "bread-loaf" approach in 1-2-mm-thick sections, and the pathologist then examines the haematoxylineosin-stained sections for malignant cells.

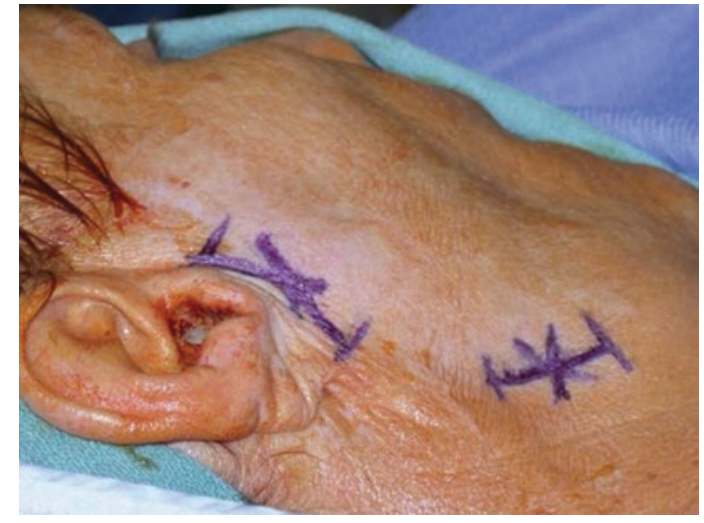

Fig. 5.3 Intraoperative surface markings after use of gamma probe

2. If no malignant cells are found, additional sections are subjected to thorough immunohistochemical analysis.

3. Recommended immunohistochemical (IHC) markers: 


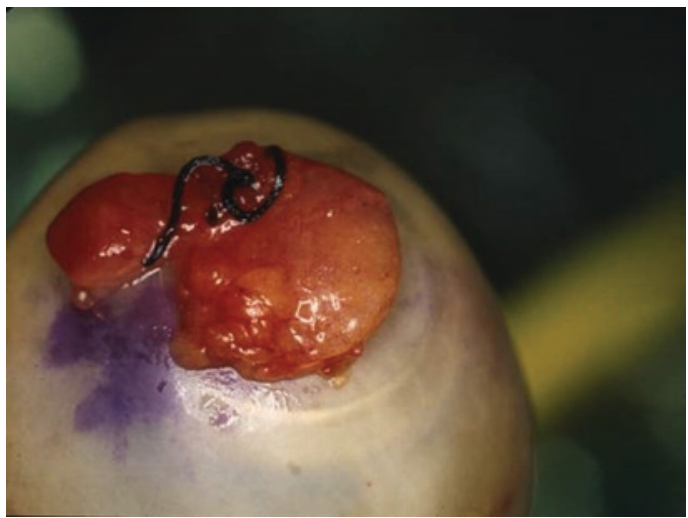

Fig. 5.4 Surgically excised lymph node

(a) Melanoma-antimelanocytic cocktail with HMB-45, anti-MART 1, and anti-tyrosinase $[23,24]$

(b) Squamous carcinoma-anticytokeratin antibody cocktail with cytokeratin AE-1/ AE-3 [25]

(c) Merkel cell carcinoma-antibodies to Cam5.3, chromogranin, and cytokeratin 20 $[26,27]$

(d) Sebaceous gland carcinoma-antiadipophilin and anti-perilipin antibodies [28-30]

\section{SLN Positivity and False-Negative Results}

A review of the published literature on SLNB for ocular adnexal tumors shows variable results of SLN positivity. Savar et al. in a relatively large series $(n=30)$ of SLNB in ocular adnexal melanoma report positivity rate of $17 \%$ [17]. In cases with sebaceous gland carcinoma classified higher than $\mathrm{T} 2 \mathrm{~b}$ and $>10 \mathrm{~mm}$ in greatest diameter $(n=16)$; SLN positivity rate was $13 \%$ [10]. Both of these reports were generated from MD Anderson Cancer Center where a lot of the early feasibility studies for SLN biopsy for ocular adnexal cancers took place. A similar rate of $13 \%$ was also reported for squamous cell carcinoma $(n=8)$ by French colleagues [31]. Regarding Merkel cell carcinoma, studies report a SLN positivity rate of $27-48 \%$ for all anatomic location
[32-34]. The data on Merkel cell carcinoma of eyelid is insufficient to determine the positivity rate for SLN and prognosis, but there are definitely case reports and small case series of eyelid Merkel cell carcinoma with positive SLN biopsy results $[10,35,36]$.

A case with histologically negative SLNs and subsequent development of nodal metastasis constitutes a false-negative event. The causes for false-negative events are cited as steep learning curve for SLNB for ocular adnexal as well as head and neck tumors, scarring from multiple prior surgeries at tumor site causing changes in lymphatic drainage routes, and in the event of in-transit metastasis that goes undetected on preoperative or intraoperative lymphatic mapping, as well as inaccurate detection of microscopic metastasis in the draining lymph nodes [10]. Our group at MD Anderson Cancer Center has performed SLN biopsy for ocular adnexal tumors since 2001; we have not encountered any cases of false-negative SLN biopsy results for the last 15 years suggesting the importance of experience with this technique.

However, barring the false-negative events that are rare in experienced hands, a negative SLNB result can be reassuring to the patient. And identification of microscopic metastasis in the draining lymph nodes could mean that the patient would benefit from earlier treatments for metastatic disease.

\section{Further Considerations}

Though there is a certain risk of metastasis to regional lymph nodes associated with different conjunctival and eyelid tumors, radical neck dissection and/or parotidectomy for all tumors or empiric radiation therapy for all does not seem to be justified given the relatively low yield, radiation-related complications, and lack of improvement in survival, as described by several published studies. The first Multicenter Selective Lymphadenectomy Trial (MSLT) -I confirmed the value of early nodal evaluation and treatment. This prospective, international, randomized trial showed that the pathologic status of the sentinel node or nodes was the most important 
prognostic factor and that patients who underwent sentinel-node biopsy had fewer recurrences of melanoma than patients who underwent wide excision and nodal observation. Among patients with intermediate-thickness melanomas (defined as $1.2-3.5 \mathrm{~mm}$ ) and nodal metastases, early surgical treatment, guided by sentinel-node biopsy, was associated with increased melanoma-specific survival (survival until death from melanoma) [37-39]. These results provide support for the recommendation by several professional organizations that staging by means of sentinel-node biopsy should be performed when appropriate.

However, the subsequent management decision in patients with sentinel lymph nodepositive metastasis, in the form of completion of lymph node dissection with or without radiation therapy or observation and imaging for clinically apparent disease before radical surgery, remains controversial.

In an effort to shed some light on this controversy, the most recent report by MSLT-II involving 1934 cases of cutaneous melanoma concludes that immediate completion of lymph node dissection in SLN-positive cases increased the rate of regional disease control, reduced the rate of regional nodal recurrence by nearly $70 \%$, and provided prognostic information but did not improve melanoma-specific survival [40].

Thus, the subsequent management decision in sentinel lymph node metastasis needs to be taken at the surgeon's discretion and detailed discussion regarding disease control and survival for individual case with the patient and family.

In summary, SLNB technique is a relatively low-risk and minimally invasive procedure. It maintains a potential to offer important information to patients and surgeons in terms of accurate tumor staging and prognosis and potential for appropriate patients to receive additional surgery, radiation therapy, and/or systemic therapy for their microscopically metastatic nodal disease. The availability of immune checkpoint inhibitors for patients with metastatic melanoma and metastatic squamous carcinomas is an additional consideration making detection of early nodal metastasis more critical because of the potential for earlier treatment with this new class of drugs that has revolutionized our expectations for the length and quality of life after diagnosis of metastatic melanoma [13-16].

\section{References}

1. Esmaeli B, Youssef A, Naderi A, et al. Margins of excision for cutaneous melanoma of the eyelid skin: the collaborative eyelid skin melanoma group report. Ophthal Plast Reconstr Surg. 2003;19:96-101.

2. Faustina M, Diba R, Ahmadi MA, et al. Patterns of regional and distant metastasis in patients with eyelid and periocular squamous cell carcinoma. Ophthalmology. 2004;111:1930-2.

3. Soysal HG, Markoç F. Invasive squamous cell carcinoma of the eyelids and periorbital region. $\mathrm{Br} \mathrm{J}$ Ophthalmol. 2007;91:325-9.

4. Tryggvason G, Bayon R, Pagedar NA. Epidemiology of sebaceous carcinoma of the head and neck: implications for lymph node management. Head Neck. 2012;34:1765-8.

5. Shields JA, Demirci H, Marr BP, et al. Sebaceous carcinoma of the eyelids: personal experience with 60 cases. Ophthalmology. 2004;111:2151-7.

6. Ho VH, Ross MI, Prieto VG, et al. Sentinel lymph node biopsy for sebaceous cell carcinoma and melanoma of the ocular adnexa. Arch Otolaryngol Head Neck Surg. 2007;133:820-6.

7. Esmaeli B, Nasser QJ, Cruz H, et al. American Joint Committee on cancer $\mathrm{T}$ category for eyelid sebaceous carcinoma correlates with nodal metastasis and survival. Ophthalmology. 2012;119:1078-82.

8. Peters GB III, Meyer DR, Shields JA, et al. Management and prognosis of Merkel cell carcinoma of the eyelid. Ophthalmology. 2001;108:1575-9.

9. Pfeiffer ML, Ozgur OK, Myers JN, Peng A, Ning $\mathrm{J}$, Zafereo ME, Thakar S, Thuro B, Prieto VG, Ross MI, Esmaeli B. Sentinel lymph node biopsy for ocular adnexal melanoma. Acta Ophthalmol. 2017;95(4):e323-8.

10. Pfeiffer ML, Savar A, Esmaeli B. Sentinel lymph node biopsy for eyelid and conjunctival tumors: what have we learned in the past decade? Ophthalmic Plast Reconstr Surg. 2013 Jan 1;29(1):57-62.

11. Dutton JJ. Atlas of Clinical and Surgical Orbital Anatomy. Philadelphia: WB Saunders Co; 1994. p. 84.

12. Nijhawan N, Ross MI, Diba R, Gutstein BF, Ahmadi MA, Esmaeli B. Experience with sentinel lymph node biopsy for eyelid and conjunctival malignancies at a cancer center. Ophthalmic Plast Reconstr Surg. 2004 Jul 1;20(4):291-5.

13. Ford J, Thuro BA, Thakar S, Hwu WJ, Richani K, Esmaeli B. Immune checkpoint inhibitors for treatment of metastatic melanoma of the orbit and ocular adnexa. Ophthal Plast Reconstr Surg. 2017;33(4):e825. e-Pub 9/2016. PMID: 27662198. 
14. Schachter J, Ribas A, Long GV, Arance A, Grob JJ, Mortier L, Daud A, Carlino MS, McNeil C, Lotem M, Larkin J. Pembrolizumab versus ipilimumab for advanced melanoma: final overall survival results of a multicentre, randomised, open-label phase 3 study (KEYNOTE-006). Lancet. 2017; 390(10105):1853-62.

15. Kazandjian D, Suzman DL, Blumenthal G, Mushti S, He K, Libeg M, Keegan P, Pazdur R. FDA approval summary: nivolumab for the treatment of metastatic non-small cell lung cancer with progression on or after platinum-based chemotherapy. Oncologist. 2016 May 1;21(5):634-42.

16. Yun S, Vincelette ND, Green MR, Wahner Hendrickson AE, Abraham I. Targeting immune checkpoints in unresectable metastatic cutaneous melanoma: a systematic review and meta-analysis of anti-CTLA-4 and anti-PD-1 agents trials. Cancer Med. 2016 Jul 1;5(7):1481-91.

17. Savar A, Ross MI, Prieto VG, et al. Sentinel lymph node biopsy for ocular adnexal melanoma: experience in 30 patients. Ophthalmology. 2009;116:2217-23.

18. Paek SC, Griffith KA, Johnson TM, et al. The impact of factors beyond Breslow depth on predicting sentinel lymph node positivity in melanoma. Cancer. 2007;109:100-8.

19. Schwartz JL, Griffith KA, Lowe L, et al. Features predicting sentinel lymph node positivity in Merkel cell carcinoma. J Clin Oncol. 2011;29:1036-41.

20. Tuomaala S, Kivelä T. Metastatic pattern and survival in disseminated conjunctival melanoma: implications for sentinel lymph node biopsy. Ophthalmology. 2004;111:816-21.

21. Tuomaala S, Toivonen P, Al-Jamal R, et al. Prognostic significance of histopathology of primary conjunctival melanoma in Caucasians. Curr Eye Res. 2007;32:939-52.

22. Amato M, Esmaeli B, Ahmadi MA, et al. Feasibility of preoperative lymphoscintigraphy for identification of sentinel lymph nodes in patients with conjunctival and periocular skin malignancies. Ophthal Plast Reconstr Surg. 2003;19:102-6.

23. Prieto VG. Sentinel lymph nodes in cutaneous melanoma: handling, examination, and clinical repercussion. Arch Pathol Lab Med. 2010;134:1764-9.

24. Spanknebel K, Coit DG, Bieligk SC, et al. Characterization of micrometastatic disease in melanoma sentinel lymph nodes by enhanced pathology: recommendations for standardizing pathologic analysis. Am J Surg Pathol. 2005;29:305-17.

25. Trivedi NP, Ravindran HK, Sundram S, et al. Pathologic evaluation of sentinel lymph nodes in oral squamous cell carcinoma. Head Neck. 2010;32:1437-43.

26. Allen PJ, Busam K, Hill AD, et al. Immunohistochemical analysis of sentinel lymph nodes from patients with Merkel cell carcinoma. Cancer. 2001;92:1650-5.

27. Pulitzer MP, Amin BD, Busam KJ. Merkel cell carcinoma: review. Adv Anat Pathol. 2009;16:135-44.

28. Ansai S, Takeichi H, Arase S, et al. Sebaceous carcinoma: an immunohistochemical reappraisal. Am J Dermatopathol. 2011;33:579-87.

29. Izumi M, Mukai K, Nagai T, et al. Sebaceous carcinoma of the eyelids: thirty cases from Japan. Pathol Int. 2008;58:483-8.

30. Muthusamy K, Halbert G, Roberts F. Immunohistochemical staining for adipophilin, perilipin and TIP47. J Clin Pathol. 2006;59:1166-70.

31. Maalouf TJ, Dolivet G, Angioi KS, et al. Sentinel lymph node biopsy in patients with conjunctival and eyelid cancers: experience in 17 patients. Ophthal Plast Reconstr Surg. 2012;28:30-4.

32. Shnayder Y, Weed DT, Arnold DJ, et al. Management of the neck in Merkel cell carcinoma of the head and neck: University of Miami experience. Head Neck. 2008;30:1559-65.

33. Warner RE, Quinn MJ, Hruby G, et al. Management of Merkel cell carcinoma: the roles of lymphoscintigraphy, sentinel lymph node biopsy and adjuvant radiotherapy. Ann Surg Oncol. 2008;15:2509-18.

34. Maza S, Trefzer U, Hofmann M, et al. Impact of sentinel lymph node biopsy in patients with Merkel cell carcinoma: results of a prospective study and review of the literature. Eur J Nucl Med Mol Imaging. 2006;33:433-40.

35. Sniegowski MC, Warneke CL, Morrison WH, Nasser QJ, Frank SJ, Pfeiffer ML, El-Sawy T, Esmaeli B. Correlation of American Joint Committee on cancer $\mathrm{T}$ category for eyelid carcinoma with outcomes in patients with periocular Merkel cell carcinoma. Ophthal Plast Reconstr Surg. 2014;30(6):480-5.

36. Esmaeli B, Naderi A, Hidaji L, Blumenschein G, Prieto VG. Merkel cell carcinoma of the eyelid with a positive sentinel node. Arch Ophthalmol. 2002;120:650-2. PMID: 12003618.

37. Morton DL, Cochran AJ, Thompson JF, et al. Sentinel node biopsy for early stage melanoma: accuracy and morbidity in MSLT-I, an international multicenter trial. Ann Surg. 2005;242:302-11.

38. Morton DL, Thompson JF, Cochran AJ, et al. Sentinelnode biopsy or nodal observation in melanoma. $\mathrm{N}$ Engl J Med. 2006;355:1307-17.

39. Morton DL, Thompson JF, Cochran AJ, et al. Final trial report of sentinel-node biopsy versus nodal observation in melanoma. N Engl J Med. 2014;370:599-609.

40. Faries MB, Thompson JF, Cochran AJ, Andtbacka RH, Mozzillo N, Zager JS, Jahkola T, Bowles TL, Testori A, Beitsch PD, Hoekstra HJ. Completion dissection or observation for sentinel-node metastasis in melanoma. N Engl J Med. 2017 Jun 8;376(23):2211-22. 
Open Access This chapter is licensed under the terms of the Creative Commons Attribution 4.0 International License (http://creativecommons.org/licenses/by/4.0/), which permits use, sharing, adaptation, distribution and reproduction in any medium or format, as long as you give appropriate credit to the original author(s) and the source, provide a link to the Creative Commons license and indicate if changes were made.

The images or other third party material in this chapter are included in the chapter's Creative Commons license, unless indicated otherwise in a credit line to the material. If material is not included in the chapter's Creative Commons license and your intended use is not permitted by statutory regulation or exceeds the permitted use, you will need to obtain permission directly from the copyright holder. 